\title{
Trends and risks of developing local consumer markets in rural areas
}

\author{
Elena Dvoryadkina, Larissa Khacheva, and Natalia Istomina \\ Ural State University of Economics, Ekaterinburg, Russia
}

\begin{abstract}
The paper considers trends and risks of development of local consumer markets of rural territories, measures of state programs aiming at sustainable developing consumer markets. The concepts of municipalities of rural territories and consumer markets of rural territories are given. The main indicators of the consumer market, such as turnover of retail trade and catering, as well as indicators of the consumer service sector, are analyzed.
\end{abstract}

\section{Introduction}

Providing for socio-economic development of rural territories is traditionally among priorities of public policy, one of the effective mechanisms for the implementation of the latter being government and national programs.

The national program is a document of strategic planning, containing a package of planned measures interconnected in terms of tasks, dates, executing officers and resources, and state policy instruments ensuring within the framework of the implementation of key state functions the achievement of priorities and goals of public policy in the field of socioeconomic development and national security of the Russian Federation [1]. The national program is the most important means of implementing domestic public policy focused on developing social and economic spheres of life, and it should be aimed at carrying out large scientific and investment projects to solve complex problems within the bounds of federal, regional and local authorities. While working on the annual federal budget the government adopts dozens of programs to be financed.

The main documents of public strategy and programming in the context of the objectives of the present research are the following : "Strategy for the Sustainable Development of Rural Territories of the Russian Federation till 2030" adopted by the Government of the Russian Federation dated February 2, 2015 No. 151-r, the National Programs "Integrated Development of Rural Territories" adopted by the Government of the Russian Federation dated May 31, 2019 No. 696, "Development of Agriculture and Regulation of Markets of Agricultural Products, Raw Materials and Food" adopted by the Government of the Russian Federation dated July 14, 2012 No. 717. [2-4].

Local consumer markets in rural areas are therefore an integral component of rural socio-economic development. 


\section{Materials and Methods}

The analysis of modern processes and trends in the development of rural areas is done in the works of such domestic scientists as Nefedova T. G.[5], Treivish A. I. [6], Gazizov R. M. [7], Darmograi O. V. [8], Dvoryadkina E. B., Belousova E. A. [9], Ilinykh A.V. [10], Kleymenov D. S. [11], Kovtun B. A., Papelo V. N., Yarmanov V. V. [12] and others. Local consumer markets of municipalities are studied from different viewpoints by such scientists as Kovaleva I. V., Kucherenko T. V. [13], Nikiforova O. P., Antokhonova I. V. [14], Chernysheva E. V. [15], Razorvin I. V., Usova N. V., Bardasova N. V. [16] and others.

In order to analyze trends in the development of local consumer markets of municipalities of the Sverdlovsk region, we use the statistic data provided by Rosstat (Current Statistical Survey). Being typical rural territories, the above municipalities act as a testing ground for the study of local consumer markets. The concept of 'rural territories' is a collective one since it may embrace various elements of administrative-territorial or municipal-territorial structure. E.B. Dvoryadkina and E.A. Belousova defined the concept of 'rural-type municipality'. "This municipality, as a kind of territorial structure of local self-government, has a special economic and legal status related to the laws of functioning of rural economy, and, unlike rural territories, it can be unambiguously identified as an object of statistical service in order to optimize interaction in the system of population-local self-government- production complex "[17]. Rural-type municipalities thus include municipal areas and rural settlements.

\section{Results and Discussion}

To fulfill the national program "Development of Agriculture and Regulation of Agricultural Product, Raw Material and Food Markets for 2013-2020," the Government of the Sverdlovsk region adopted a similar target program "Development of the Agro-industrial Complex and Consumer Market of the Sverdlovsk Region till 2025" [18]

The regulatory framework of the program includes the following legal acts: Federal Law of 29.12.2006. No. 264-FZ "On the Development of Agriculture", the Doctrine of Food Security of the Russian Federation approved by the Russian President (the Decree of 30.01.2010), "The Concept of Long-term Social and Economic Development of the Russian Federation till 2020" dated 17.11.2008 No. 1662-r, "The Methodical Instructions of the Ministry of Economic Development of the Russian Federation on Development and Implementation of State Programs of the Russian Federation" adopted by the Ministry of Economic Development of the Russian Federation dated 22.11.2013 No. 690 [19-22].

The proposed measures, carried out within the framework of the national program "Development of the Agro-industrial and Consumer Market of the Sverdlovsk Region till 2025," are based on the following principles:

- stability. The new program retains effective directions and measures to support agriculture;

- systemacy. The program covers economic, social and environmental aspects of development of the above branch and combines support measures with market regulation and rural development;

- co-financing. The implementation of the program measures involves co-financing of agriculture from the federal and regional budgets;

- government and private partnership. It involves joint efforts of the government and business to achieve the objectives of the program. [23]

The goals and objectives of the public program of the Sverdlovsk region "Development of the Agro-industrial Complex and the Consumer Market of the Sverdlovsk Region till 
2025" correspond to the goals and objectives of the main strategic documents: "Strategies for the Development of the Food and Processing Industry of the Russian Federation for the period up to 2020", adopted by the Government of the Russian Federation, dated 17.04.2012 N 559-r, "Strategies for the Sustainable Development of Rural Territories of the Russian Federation for the Period up to 2030" adopted by the Government of the Russian Federation, dated 02.02.2015 N 151-r, "Strategies for the Socio-economic Development of the Sverdlovsk region for 2016 - 2030" adopted by the Government of the Sverdlovsk Region with the law dated December 21, 2015 N 151-OZ "On the Strategy for the SocioEconomic Development of the Sverdlovsk Region for 2016-2030." [24, 25]

One of the goals of subprogram "Development of the Consumer Market of the Sverdlovsk region" is to ensure effective activities of state authorities in the field of the agro-industrial complex and the consumer market. To achieve this goal one should

- improve the quality and safety of food products in the consumer market of the Sverdlovsk region;

- increase consumer awareness and literacy on issues of quality assurance, food safety and protection of consumers;

- diversify, improve quality and raise competitiveness of food produced in the Sverdlovsk region;

- develop multi-format trade;

- ensure integrated development of rural areas.

As part of the municipal structure of the Sverdlovsk region, 94 municipalities were formed within the boundaries of administrative-territorial units by January 1, 2020. They include 68 urban districts and 5 municipal districts, which consist of 5 urban settlements and 16 rural settlements. The paper gives an analysis of the consumer market of rural territories based on the above municipalities.

The methodology includes a SWOT analysis and an analysis of the most important indicators of the consumer market of rural areas in dynamics.

Table 1 presents a SWOT analysis of the consumer market to identify strengths and weaknesses of the development of the consumer market in rural areas, as well as opportunities and threats.

Table 1. SWOT Analysis of the Consumer Market (compiled by the author)

\begin{tabular}{|l|l|}
\hline \multicolumn{1}{|c|}{ Strengths (S) } & \multicolumn{1}{c|}{ Weaknesses (W) } \\
\hline $\begin{array}{l}\text { 1. Advantageous economic and geographical position } \\
\text { of the Sverdlovsk region for the development of the } \\
\text { industry. }\end{array}$ & $\begin{array}{l}\text { 1. Low solvency of part of the population, } \\
\text { especially in areas remote from the regional center. }\end{array}$ \\
\hline $\begin{array}{l}\text { 2. A steady positive trend in the development of the } \\
\text { consumer market industry in the Sverdlovsk region. }\end{array}$ & $\begin{array}{l}\text { 2. Lack of qualified specialists, high turnover of } \\
\text { personnel, weak motivation of staff to be in the } \\
\text { profession, low level of wages. }\end{array}$ \\
\hline $\begin{array}{l}\text { 3. High saturation of the market with food of local } \\
\text { production and processing, as well as agricultural } \\
\text { products. }\end{array}$ & 3. Presence of hard-to-reach remote areas. \\
\hline $\begin{array}{l}\text { 4. Regional support programs for catering enterprises } \\
\text { providing services to socially vulnerable segments of } \\
\text { the population of the Sverdlovsk region (from the } \\
\text { regional budget). }\end{array}$ & $\begin{array}{l}\text { 4. Lack of state regulation of the catering industry, } \\
\text { weak legislative framework regulating activities in } \\
\text { the domestic market of the Russian Federation. }\end{array}$ \\
\hline
\end{tabular}


Table 1. Continued

\begin{tabular}{|l|l|}
\hline $\begin{array}{l}\text { 5. Sufficient provision of the population with } \\
\text { stationary retail space and seats in enterprises of the } \\
\text { public network. }\end{array}$ & $\begin{array}{l}\text { 5. A weak material and technical base of small and } \\
\text { medium-sized catering enterprises, lack of modern } \\
\text { resource-saving equipment. }\end{array}$ \\
\hline \multicolumn{1}{|c|}{ Opportunities (O) } & Threats (T) \\
\hline $\begin{array}{l}\text { 1. Development of a system of quality control, safety } \\
\text { control of raw materials, food products and services. }\end{array}$ & $\begin{array}{l}\text { 1. Territorial asymmetry in the development of } \\
\text { municipalities, especially remote and rural } \\
\text { territories. }\end{array}$ \\
\hline $\begin{array}{l}\text { 2. State support (methodological, organizational, } \\
\text { financial ones) of public catering enterprises } \\
\text { providing services to socially unprotected segments of } \\
\text { the population of the Sverdlovsk region. }\end{array}$ & $\begin{array}{l}\text { 2. The dependence of social enterprises in } \\
\text { concluding contracts for the supply of products and } \\
\text { the provision of services on the fundamental } \\
\text { criterion of "price," which significantly affects the } \\
\text { quality of goods (services). }\end{array}$ \\
\hline $\begin{array}{l}\text { 3. Further development and improvement of the } \\
\text { network of consumer market enterprises. }\end{array}$ & $\begin{array}{l}\text { 3. Penetration into the market of counterfeit, low- } \\
\text { quality products }\end{array}$ \\
\hline 4. Development of transport infrastructure. & $\begin{array}{l}\text { 4. Increasing rural outflows to cities or more socio- } \\
\text { economically developed areas. }\end{array}$ \\
\hline
\end{tabular}

The SWOT analysis reveals a number of weaknesses and threats in the consumer market of rural territories of the Sverdlovsk region. Rural territories of the Sverdlovsk region are quite complex for the development of the consumer market. However this analysis shows that the development of multi-format infrastructure of the consumer market will eliminate the unevenness of the industry in municipal areas, the special manifestation of which is recorded in remote and inaccessible settlements.

\subsection{Analysis of consumer market indicators of municipal districts of Sverdlovsk region}

\subsubsection{Analysis of Retailing and Catering}

Table 2. Retail Turnover (without small businesses), in thousand rubles [26]

\begin{tabular}{|l|c|c|c|}
\hline Municipalities & $\mathbf{2 0 1 7}$ & $\mathbf{2 0 1 8}$ & $\mathbf{2 0 1 9}$ \\
\hline Bajkalovskij & 224281 & 312414,2 & 357248,7 \\
\hline Kamyshlovskij & 113697 & 306928 & 290109 \\
\hline Nizhneserginskij & 1840347,6 & 2416770,3 & 2401225,6 \\
\hline Slobodo-Turinsk & 404097,7 & 448305,5 & 513577,7 \\
\hline Taborinskij & 101024,4 & 112076,3 & 128394,4 \\
\hline Total & $\mathbf{2 6 8 3 4 4 7 , 7}$ & $\mathbf{3 5 9 6 4 9 4 , 3}$ & $\mathbf{3 6 9 0 5 5 5 , 4}$ \\
\hline
\end{tabular}

Table 3. The Total Volume of All Food Products Sold within the Boundaries of the Municipal District during the Financial Year, in thousand rubles. [26]]

\begin{tabular}{|l|c|c|c|}
\hline Municipalities & $\mathbf{2 0 1 7}$ & $\mathbf{2 0 1 8}$ & $\mathbf{2 0 1 9}$ \\
\hline Bajkalovskij & 437759,4 & 460635,7 & 500466,9 \\
\hline Kamyshlovskij & 571249,8 & 567406 & 569232,5 \\
\hline Nizhneserginskij & 1588716,5 & 1643208,4 & 1805920,6 \\
\hline Slobodo-Turinsk & 389868,9 & 410203,3 & 469169,5 \\
\hline Taborinskij & 46287,4 & 53854,9 & 65985,1 \\
\hline Total & $\mathbf{3 0 3 3 8 8 2}$ & $\mathbf{3 1 3 5 3 0 8 , 3}$ & $\mathbf{3 4 1 0 7 7 4 , 6}$ \\
\hline
\end{tabular}


The analysis of such indicators as 'retail turnover (without small businesses)' and 'the total volume of all food products sold within the boundaries of the municipal district during the financial year' shows positive dynamics, which indicates the sustainable development of the consumer market.

Table 4. Retailing and Catering Facilities [26]

\begin{tabular}{|l|c|c|c|}
\hline \multirow{2}{*}{ Facilities } & \multicolumn{3}{|c|}{ Number of facilities per year } \\
\cline { 2 - 4 } & $\mathbf{2 0 1 7}$ & $\mathbf{2 0 1 8}$ & $\mathbf{2 0 1 9}$ \\
\hline stores & 718 & 698 & 677 \\
\hline pavilions & 75 & 77 & 74 \\
\hline stalls and kiosks & 21 & 19 & 17 \\
\hline chemist's & 21 & 21 & 20 \\
\hline branch pharmacies & 20 & 21 & 22 \\
\hline canteens & 31 & 32 & 32 \\
\hline refectories & 84 & 84 & 85 \\
\hline hypermarkets & & & 1 \\
\hline supermarkets & 10 & 8 & 8 \\
\hline specialized grocery stores. & 96 & 95 & 93 \\
\hline specialized non-food stores & 134 & 128 & 131 \\
\hline stores discounters & 84 & 82 & 80 \\
\hline restaurants and cafes & 23 & 29 & 30 \\
\hline minimarkets & 345 & 340 & 318 \\
\hline department stores & & & \\
\hline other shops & 59 & 55 & 55 \\
\hline
\end{tabular}

The number of retail facilities has slightly decreased, which is caused by the outflow of rural residents to cities and other areas. The number of catering facilities has increased, which proves that the public catering services are in demand.

Table 5. Turnover of Catering Services, in thousand rubles [26]

\begin{tabular}{|l|c|c|c|}
\hline Municipalities & $\mathbf{2 0 1 7}$ & $\mathbf{2 0 1 8}$ & $\mathbf{2 0 1 9}$ \\
\hline Bajkalovskij & 14687,8 & 15557,4 & 18254,6 \\
\hline Kamyshlovskij & 12287,7 & 14348,5 & 12890,7 \\
\hline Nizhneserginskij & 17359 & 21300,8 & 29002 \\
\hline Slobodo-Turinsk & 12007,3 & 11944,8 & 12581,4 \\
\hline Taborinskij & 43,6 & & \\
\hline Total & $\mathbf{5 6 3 8 5 , 4}$ & $\mathbf{6 3 1 5 1 , 5}$ & $\mathbf{7 2 7 2 8 , 7}$ \\
\hline
\end{tabular}

The indicator 'public catering turnover (without small businesses)' shows positive dynamics, which indicates sustainable development of the consumer market and confirms the conclusion of Table 5 .

Table 6. Hard Drinks Sales to the Population, in thousand rubles [26]

\begin{tabular}{|l|c|c|c|}
\hline Municipalities & $\mathbf{2 0 1 7}$ & $\mathbf{2 0 1 8}$ & $\mathbf{2 0 1 9}$ \\
\hline Bajkalovskij & 51939,4 & 47485,1 & 41134,4 \\
\hline Kamyshlovskij & 15744,6 & 28226,2 & 25229,43 \\
\hline Nizhneserginskij & 128377,52 & 124477,36 & 115089,03 \\
\hline
\end{tabular}


Table 6. Continued

\begin{tabular}{|l|c|c|c|}
\hline Slobodo-Turinsk & 43985,07 & 31453,2 & 31305,98 \\
\hline Taborinskij & 43985,07 & 31453,2 & 31305,98 \\
\hline Total & $\mathbf{2 8 4 0 3 1 , 6 6}$ & $\mathbf{2 6 3 0 9 5 , 0 6}$ & $\mathbf{2 4 4 0 6 4 , 8 2}$ \\
\hline
\end{tabular}

The indicator 'hard drinks sales to the population' has significantly reduced, which may indicate the effectiveness of the government social policy.

\subsubsection{Analysis of Consumer Services}

Table 7. Consumer Service Establishments [26]

\begin{tabular}{|l|c|c|c|}
\hline \multirow{2}{*}{ Consumer Service Establishments } & \multicolumn{3}{l}{ Number of facilities per year } \\
\cline { 2 - 4 } & \multicolumn{2}{l|}{} \\
\cline { 2 - 4 } & $\mathbf{2 0 1 7}$ & $\mathbf{2 0 1 8}$ & $\mathbf{2 0 1 9}$ \\
\hline Total & 162 & 173 & 177 \\
\hline shoe repair & 6 & 4 & 3 \\
\hline repair of fur products & 15 & 11 & 12 \\
\hline repair of electronic equipment & 2 & 5 & 6 \\
\hline service centers & 32 & 35 & 39 \\
\hline furniture manufacturing & 13 & 16 & 16 \\
\hline dry cleaner's & & & 0 \\
\hline laundries & & & 0 \\
\hline housing repairs & 4 & 6 & 7 \\
\hline baths, showers and saunas & 6 & 6 & 7 \\
\hline hairdresser's/barber's & 31 & 32 & 32 \\
\hline photographer's & 15 & 10 & 12 \\
\hline undertaker's & 19 & 15 & 14 \\
\hline Other services & 19 & 33 & 29 \\
\hline
\end{tabular}

Table 8. Number of Chairs in the Hairdresser's/Barber's [26]

\begin{tabular}{|l|c|c|c|}
\hline Municipalities & $\mathbf{2 0 1 7}$ & $\mathbf{2 0 1 8}$ & $\mathbf{2 0 1 9}$ \\
\hline Bajkalovskij & 14 & 15 & 12 \\
\hline Kamyshlovskij & 9 & 12 & 12 \\
\hline Nizhneserginskij & 24 & 24 & 25 \\
\hline Slobodo-Turinsk & 8 & 8 & 8 \\
\hline Taborinskij & 1 & 1 & 1 \\
\hline Total & $\mathbf{5 6}$ & $\mathbf{6 0}$ & $\mathbf{5 8}$ \\
\hline
\end{tabular}

Such indicators as 'amount of consumer service facilities' and 'amount of chairs in hairdresser's/ barber's' show a slight decrease in the number of facilities.

\subsubsection{Analysis of per Capita Indicators}

Table 9. Per Capita Indicators

\begin{tabular}{|l|c|c|c|}
\hline \multicolumn{1}{|c|}{ Indicators } & $\mathbf{2 0 1 7}$ & $\mathbf{2 0 1 8}$ & $\mathbf{2 0 1 9}$ \\
\hline Retail turnover per capita(without small businesses) & 26,83 & 36,15 & 37,3 \\
\hline Total food commodities per capita (without small businesses & 30,34 & 31,52 & 34,47
\end{tabular}


Table 9. Continued

\begin{tabular}{|l|c|c|c|}
\hline Trading rooms per capita & 0,94 & 0,98 & 0,97 \\
\hline Service rooms in catering facilities per capita & 0,124 & 0,128 & 0,132 \\
\hline
\end{tabular}

Per capita indicators in rural areas are lower than the ones in urban areas. This proves a lower living standard of rural residents.

\section{Conclusion}

The consumer market of rural areas is an integral part of rural economy. Its sustainable development ensures developing rural areas, improving quality of life of rural residents, and contributes to the development of the agro-industrial complex. Retail and catering industries show positive dynamics. This fact indicates a stable development of the consumer market. The Sverdlovsk region shows the following trends in developing consumer services, typical of the Russian Federation on the whole:

- a gradual decrease in demand for a number of traditional consumer services, which are supplanted by the increased technological equipment of the household. The analysis of the consumer market in terms of consumer services in rural areas of the Sverdlovsk region shows that the structure of consumer services is still dominated by consumer services of the traditional type. The consumer markets, aiming at the high-income segment of services based on the desire to improve the quality of life, mobility and rational use of free time, are not expanding in rural areas. This also indicates the existing problems in the field of consumer services, such as: a poorly developed infrastructure of consumer services, a shortage of a fixed network of consumer services in rural areas, a low level of development of mobile forms of service provision; an undeveloped system of inter-municipal relations of consumer service organizations in carrying out joint projects that contribute to the development of the consumer services market; a lack of qualified personnel in the field of consumer services, the lack of prestige of consumer service professions.

\section{References}

1. State programs of the Russian Federation, Official site of the Standing Committee of the Union State. M., (2010) https://www.postkomsg.com/

2. Order of the Government of the Russian Federation dated 02.02.2015 No. 151-r "On approval of the Strategy for sustainable development of rural areas of the Russian Federation for the period up to 2030", Official website of the Government of Russia, http://static.government.ru/

3. Decree of the Government of the Russian Federation dated May 31, 2019 No. 696 "On approval of the state program of the Russian Federation" Integrated development of rural areas "and amendments to some acts of the Government of the Russian Federation", Official Internet portal of legal information, http://publication.pravo.gov.ru/

4. Decree of the Government of the Russian Federation of July 14, 2012 No. 717 "On approval of the State program for the development of agriculture and regulation of markets for agricultural products, raw materials and food for 2013-2020", Official website of the Government of Russia. M., http://static.government.ru/

5. T.G. Nefedova, Spatial Economics, 15(4), 36-56. (2019)

6. A. I. Treivish, Questions of geography, 141, 51-71 (2016) 
7. R.M. Gazizov, Bulletin of the Krasnoyarsk State Agrarian University, 11, 348-351 (2013)

8. O. V. Darmogray, Improving the management of the socio-economic development of rural municipalities, 24 (2010)

9. E. B. Dvoryadkina, E.A. Belousova, Regional economy: theory and practice, 15(12), 2255-2272 (2017)

10. A.V. Ilinykh, Bulletin of the Chelyabinsk State University, 25(380), 44-48 (2015)

11. D.S. Kleymenov, Improving the management of the development of rural areas, 23 (2016)

12. B. A. Kovtun, V. N. Papelo, V. V. Yarmanov, Comprehensive development of rural areas: factors, institutions and mechanisms of advanced development, 400 (2019)

13. I.V. Kovaleva, T.V. Kucherenko, International Journal of Humanities and Natural Sciences, 4-2, 173-176 (2019)

14. O.P. Nikiforova, I. V. Antokhonova, Local food markets in new conditions: research methodology and methods of regulation, 164 (2016)

15. E.V. Chernysheva, Loyalty of consumers of products of local enterprises of the agroindustrial complex in local markets: formation in the organizational and cultural context of the regions, 88 (2015)

16. I.V. Razorvin, N.V. Usova, N.V. Bardasova, Agrarian Bulletin of the Urals, 6, 9398 (2019)

17. E. B. Dvoryadkina, E.A. Belousova, Bulletin of SUSU, Series "Economics and Management", 12(1), 48 (2018)

18. Decree of the Government of the Sverdlovsk region of 23.10.2013 No. 1285-PP "On approval of the state program of the Sverdlovsk region" Development of the agroindustrial complex and the consumer market of the Sverdlovsk region until 2025, Electronic fund of legal and normative-technical documentation, http://docs.cntd.ru/

19. Federal Law of December 29, 2006 No. No. 264-FZ "On the development of agriculture", ConsultantPlus, http://www.consultant.ru/

20. Decree of the President of the Russian Federation of January 30, 2010 No. 120 "On the approval of the Doctrine of food security of the Russian Federation", Official site of the President of Russia, http://kremlin.ru/

21. Order of the Government of the Russian Federation of November 17, 2008 No. 1662-r "Concept of long-term socio-economic development of the Russian Federation for the period up to 2020", Official website of the Government of Russia, http://static.government.ru/

22. Order of the Ministry of Economic Development of the Russian Federation dated November 20, 2013 No. 690 "On Approval of Guidelines for the Development and Implementation of State Programs of the Russian Federation", Official Internet Portal of Legal Information, http://pravo.gov.ru/

23. A.A. Izmalkov, Bulletin of the Voronezh State Agrarian University, 1-2, 211-217 (2014)

24. Order of the Government of the Russian Federation of 17.04.2012 No. 559-r "Strategy for the development of the food and processing industry of the Russian Federation for the period until 2020", Official website of the Government of Russia, http://government.ru/ 
25. Law of the Sverdlovsk region dated 21.12.2015 No. 151-OZ "On the strategy of socioeconomic development of the Sverdlovsk region for 2016-2030", Electronic fund of legal and normative-technical documentation, http://docs.cntd.ru/

26. Database of indicators of municipalities of the Sverdlovsk region, Federal State Statistics Service, https://gks.ru/ 